\title{
Stock and Flow of Carbon in Plant Woody Debris in Two Different Types of Natural Forests in Bateke Plateau, Central Africa
}

\author{
Averti S. Ifo ${ }^{1}$, Felix Koubouana ${ }^{2}$, Charlotte Jourdain ${ }^{3}$, Dominique Nganga ${ }^{4}$ \\ ${ }^{1}$ Département des Sciences Naturelles, Ecole Normale Supérieure, Université Marien Ngouabi, Brazzaville, \\ République du Congo \\ 2ENSAF, Laboratoire d’Ecologie Appliquée et d’Environnement, Université Marien Ngouabi, Brazzaville, \\ République du Congo \\ ${ }^{3}$ Forestière, Programme ONU-REDD, Organisation des Nations Unies pour l'Alimentation et l'Agriculture, \\ Brazzaville, République du Congo \\ ${ }^{4}$ Faculté des Sciences et Techniques, Université Marien Ngouabi, Brazzaville, République du Congo \\ Email: ifo.suspense@hotmail.fr
}

Received 20 December 2014; accepted 4 January 2015; published 14 January 2015

Copyright (C) 2015 by authors and Scientific Research Publishing Inc.

This work is licensed under the Creative Commons Attribution International License (CC BY). http://creativecommons.org/licenses/by/4.0/

c) (i) Open Access

\begin{abstract}
In order to know the role of plant woody debris in the carbon cycle, a study of carbon stocks and carbon flow of plant woody debris was conducted in the natural forests of the centre of the republic of Congo in the Bateke Plateau. Allometric equations were used to measure the carbon stock of in dead wood debris of Lesio-louna tropical rainforest. Three plots of $40 \mathrm{~m} \times 40 \mathrm{~m}$ were delimited in each forest types. All plots were within $300 \mathrm{~m}$ of each other. The average stocks of carbon in coarse woody debris obtained are $10993 \mathrm{~g} \cdot \mathrm{m}^{-2}$ and $14172 \mathrm{~g} \cdot \mathrm{m}^{-2}$, respectively, in the Gallery forest (GF) and the hill-slope forest clump (HF), the difference of carbon stock between the two forests is not significant $(p=0.78)$. The interannual mean flow in both forests is respectively 1776 and $545 \mathrm{~g} \cdot \mathrm{m}^{-2} \cdot \mathrm{an}^{-1}$ in the FG and the MSDS; this medium is not significant $(\mathrm{p}=0.10)$. Carbon stocks of fine woody debris are respectively 965 and $83 \mathrm{~g} \cdot \mathrm{m}^{-2}$ in the GF and HF, difference is significant ( $p=0.0013)$. The interannual mean flow of carbon in fine woody debris in the GF and the HF were respectively $310 \mathrm{~g} \cdot \mathrm{m}^{-2} \cdot \mathrm{an}^{-1}$ and $51 \mathrm{~g} \cdot \mathrm{m}^{-2} \cdot \mathrm{an}^{-1}$.
\end{abstract}

\section{Keywords}

Coarse Woody Debris, Fine Woody Debris, Carbon, Bateke Plateau, Republic of Congo

How to cite this paper: Ifo, A. S., Koubouana, F., Jourdain, C., \& Nganga, D. (2015). Stock and Flow of Carbon in Plant Woody Debris in Two Different Types of Natural Forests in Bateke Plateau, Central Africa. Open Journal of Forestry, 5, 38-47. http://dx.doi.org/10.4236/ojf.2015.51005 


\section{Introduction}

The vegetation of Central Africa is broadly composed of the Congo drainage basin and contiguous humid closedcanopy forests and less well known, coarse areas of savannah and forest-savannah mosaics often composed of forest groves either along the river bank (gallery forest) or resulting from ancient local human activities (Schartz et al., 1996). These are highly dynamic ecosystems, with some evidence that since recently the forest is encroaching into the savannah area (Delegue et al., 2001; Favier et al., 2004; Mitchard et al., 2009). Several studies have been conducted in this area of the Bateke Plateau (Makany, 1976; Schwartz \& Namri, 2002; Ifo \& Nganga, 2011; Ekouloungou et al., 2014) in order to better understand the knowledge or vegetation dynamics vegetation of the Bateke Plateau). As of today no specific study of woody debris has been undertaken in this area.

Coarse woody debris (cwd) refers to the woody material on the forest floor, including fallen stems, large branches, coarse roots, wood pieces, and standing dead trees (snags) (Harmon et al., 1986).

Woody debris is an important compartment of forest ecosystems. They participate to the structure and functioning of forest ecosystems (Harmon et al., 1986; Samuelsson et al., 1994; Francklin et al., 1987; Eaton, 2005). The first studies on the woody debris began in 1955 (Jessen, 1955), and they were the result of the mortality of forest canopy trees that produced coarse amounts of woody debris which accumulated on the ground (Harmon et al., 1986; Carmona et al., 2002).

For several decades, the characterization of the production of forests around the world was to measure fine litterfall (Bernhard-Silva, 1993; Loumeto, 2002; Goma-Tchimbakala \& Bernhard-Silva, 2006; Pandey et al., 2007) but also of fine roots (Jourdan et al., 2008; Jiménez et al., (2009)) those relating to the production, quantification and the ecology of woody debris were scarce until very recently.

And existing studies on the woody debris have been conducted in different types of forest: mangrove forests (Krauss \& Doyle, 2005), boreal forest (Karjalainen \& Kuuluvainen, 2002), temperate forest (Gove et al., 2002; Gough et al. 2007; Rahman et al. 2008; Pesonen et al., 2009), rainforest (Beets et al., 2008).

Interest in the study of plant woody debris was developed following studies on biogeochemical cycles in the forest in the context of climate change (Pittman, 2005; Eaton, 2005). In the North American temperate forests, coarse woody debris constitutes nearly 12 percent of the total carbon of the forest ecosystem. However, the amount of wood residue varies greatly from one continent to another (Turner et al., 1995; Bhatti et al., 2002; Gough et al. (2007)). Several causes could explain the variability of coarse woody debris production between types of forests: species, age, wind, fire, disease, chemical poverty of the soil, wood density, etc. (Harmon et al., 1986; Chambers, 1998; Clark et al., 2002).

Previous studies on coarse woody debris have addressed a variety of topics including descriptive inventory to estimate stock and decay classes of woody debris, dynamics of decomposition, woody debris and biogeochemical cycle, role of debris in wildlife in forest areas (Maser \& Hatch, 1984; Harmon et al., 1986; Freedman et al., 1996; Fraver et al., 2002; Kraigher et al., 2002; Pedlar et al., 2002; Woodal \& Liknes, 2008; Rahman et al., 2008; Woodall \& Likness, 2008).

Quantification of stocks and flows of plant woody debris are an important indicator of the State of the disruption or stability of a forest ecosystem (Rice et al., 2004; Baker et al., 2007), and allows to determine its causes. Coarse woody debris informs us about the history of recent disturbances that occurred in the study site.

Woody debris is an important pool of carbon in forest ecosystems both as a source and sink of $\mathrm{CO}_{2}$ to the atmosphere (Wendy et al., 2006; Frank et al., 2004; Baker et al., 2007).

The proportion of carbon in plant woody debris is function not only of the carbon content in the wood but also its density and the type of organ of plant, the stage of decomposition but also the plant species. In general organic matter contains approximately 50 percent of carbon (Mackensen and Bauhus, 1999), but this could vary between species. For example, leaf litter usually contains low rates of carbon compared to other organ of plant. Chee et al. (1999) found a rate of 40 percent of carbon for the litter of Pinusradiate, while Woldendorp et al. (2002) found percentages for carbon of 45 percent for various species of the genus Eucalyptus.

Our study was conducted in the savannah of the Bateke Plateau which contains one of the densest areas of savannah-forest mosaic of central Africa. In Republic of Congo, Bateke Plateau covers 12,000 km ${ }^{-2}$. The climate, with annual rainfall of approximately $2100 \mathrm{~mm}$, and a relatively short dry season ( 2 - 4 months), suggests there should be humid closed-canopy tropical forest on the Plateau. The predominance of savannah in this region results from a combination of frequent fires, poor sandy soils and possible slow rebound of the vegetation from the drier conditions that occurred over the last glacial maximum (Vincens et al., 1999). The objective of 
our study is to compare stocks and flows of coarse and fine woody debris in two types of tropical forest of the Bateke Plateau.

\section{Materials and Methods}

\subsection{Study Site}

The study sites are located at Iboubikro ( $\left.3^{\circ} 11^{\prime} \mathrm{S}, 15^{\circ} 28^{\prime} \mathrm{E}\right), 140 \mathrm{~km}$ North East of Brazzaville on the Plateau Teke (Figure 1). The average annual rainfall is $2100 \mathrm{~mm}$ (2006-2008) with a marked dry season from June to September and an annual average air temperature of $26^{\circ} \mathrm{C}$. The soil is a deep acidic sandy arenosol with clay content varying from 0.3 to 7.6 percent (Schwartz \& Namri, 2002).

The two forest groves of the study were a Gallery Forest (GF) with many individuals of Colletoecema dewevrei (De Wild.) [Rubiaceae] and Eriocoelum microspermum (De Wild.) Radlk. [Sapindaceae] and a hill-slope forest clump (HF) dominated by Musangacecropioides R. Br. [Cecropiaceae] and MacarangabarteriMull.Arg. [Euphorbiaceae]. Three plots of $40 \mathrm{~m} \times 40 \mathrm{~m}$ were delimited in each forest types. All plots were within $300 \mathrm{~m}$ of each other. The height of the canopy was approximately 20 - 26 in GF and $15-21 \mathrm{~m}$ in HF. Tree density was 640 stems $\cdot \mathrm{ha}^{-1}$ in GF and 119 stems $\cdot \mathrm{ha}^{-1}$ in HF (diameter at breast height above $0.1 \mathrm{~m}$ ) and the basal area was, respectively 17 and $7 \mathrm{~m}^{2} \cdot \mathrm{ha}^{-1}$.

\subsection{Coarse Woody Debris (CWD) Diameter $\emptyset \geq 2.5 \mathrm{~cm}$ : Logs and Snag}

Coarse woodv debris was defined in this studv as all woodv debris lving on the ground with a diameter $\varnothing \geq 2.5 \mathrm{~cm}$. The method called "line intersects" was used. It is an old method, used for the first time by Waren \& Olsen (1964) and that is now used by several authors (Krauss \& Doyle, 2005; Eaton \& Lawrence, 2006).

The intersection method requires that: 1 . the length of the transect line is defined; 2 . the diameter of each plant woody debris sampled is registered; 3 . only plant woody debris crossed by the line of intersection are sampled.

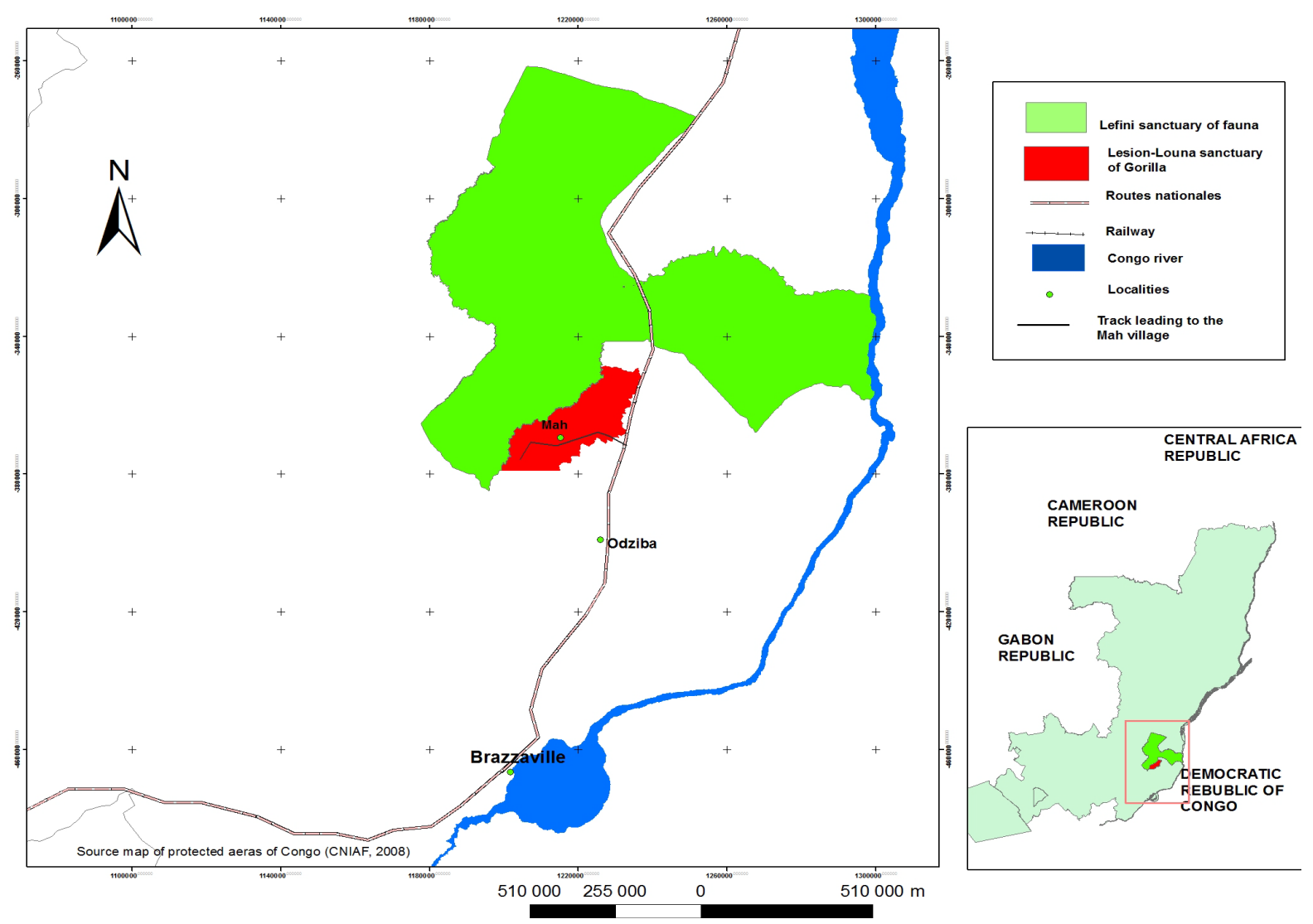

Figure 1. Map of the study area. 


\subsubsection{Log Sampling Methods}

Inside each plots of $40 \mathrm{~m} \times 40 \mathrm{~m}$, all CWD was censed. At the point of intercessions between the line transect and the CWD, the diameter of CWD was collected and the position with to the end of the diagonal is registered also. This sampling was done on the two diagonals of the plot. Data collection is done once a year with the same measurement in repeated the following years to estimate flows of CWD.

The following equation proposed by Waren \& Olsen (1964) was used to calculate the volume of deadwood accumulated on the ground.

$$
v=\frac{\pi^{2}\left(\sum d i^{2}\right)}{8 L}
$$

$V=$ volume of CWD $\left(\mathrm{m}^{3} \cdot \mathrm{ha}^{-1}\right)$;

$d i$, is the diameter of each woody debris censed (m);

$L=$ the length of line transect $(\mathrm{m})$;

Necromass $(M)$ was obtained by the following equation

$$
M=V \times 0.48 \mathrm{Kg} \cdot \mathrm{MS} \cdot \mathrm{m}^{-3}
$$

\subsubsection{Snags Collecting Data}

Snags are an important component of carbon sequestration in the forest ecosystems. Inside the experimental design plot we collected all standing dead wood with a height greater than $1.3 \mathrm{~m}$ and diameter at $d b h \geq 10 \mathrm{~cm}$.

The volume of standing dead woody debris was calculated from Equation (3) next:

$$
V s=\left(\frac{d b h}{2}\right)^{2} \times \pi \times h \times f
$$

$V_{S}=$ Volume of snag $\left(\mathrm{m}^{3}\right)$;

$D b h=$ diameter at breasth eight $(\mathrm{m})$;

$h=$ height of snag (m);

$f=$ coefficient factor form (0.627).

This formula has been used by Mund (2004). Necromass was determined by applying wood density.

\subsection{Fine Woody Debris (FWD) $\emptyset \leq 2.5 \mathrm{~cm}$}

3 subplots of $2 \mathrm{~m} \times 2 \mathrm{~m}$ were randomly positioned to quantify fine woody debris (fwd) inside each experimental plot $(40 \mathrm{~m} \times 40 \mathrm{~m})$. All fwd inside the subplot was estimated by the measurement of the diameter of the two ends of the fwd and the length of this fine woody debris (fwd). Afterwards, the fwd was removed from the subplot so as not to skew the calculation of the average residence time (ART).

$$
T_{\text {pdl }}=\frac{\text { Stock de PDL au sol }\left(\mathrm{Kg} \cdot \mathrm{m}^{-2}\right)}{\text { Flu } \times \text { de PDL }\left(\mathrm{Kg} \cdot \mathrm{m}^{-2} \cdot \mathrm{an}^{-2}\right)}
$$

Equation (4) was used assuming that the dead woody debris had cylindrical shape: this formula has been used by some authors including Baker et al. (2007).

$$
V=L\left[\frac{\pi\left(D_{1} / 2\right)^{2}+\pi\left(D_{2} / 2\right)^{2}}{2}\right]
$$

$V=\mathrm{M}^{3}$;

$L=$ length of the sample of dead wood;

$D_{1}$ and $D_{2}$ diameter of the woody debris at the two ends.

Furthermore this sampling allows us to calculate the mass of fwd on the ground from the total volume of fwd on the ground.

\subsection{CWD Decay Classes}

The CWD decay classes of are studied along the line transect by the appreciation of the qualitative aspect of the 
woody debris, on the basis of the resistance of wood to penetration of a metal (in our study a knife) into the body of the plant woody debris (Lambert et al., 1980; Clark et al., 1998). Four decay classes of plant woody debris were defined following the Protocol detailed in the methodological chapter.

\subsection{Data Analysis}

Data analysis was done through the SAS 9.0 software. We conducted an analysis of variance to compare the average of stocks and flows of carbon in woody debris plants between the two types of forest.

\section{Results}

\subsection{Carbon Stocks and Flows of Logs}

The average carbon stock of Logs in GF was $10,993 \mathrm{~g} \cdot \mathrm{m}^{-2}$ while we obtained in the HF a carbon stock of 14,172 $\mathrm{g} \cdot \mathrm{m}^{-2}$ (ANOVA, $p=0.78$ ). The interannual mean C flows in both forests was respectively 1776 and $545 \mathrm{~g} \cdot \mathrm{m}^{-2} \cdot \mathrm{y}^{-1}$, (ANOVA, $p=0.10$ ). Noting that the average flows of CWD in the GF was 3.26 times more important in GF than in the HF.

C Stocks of Fine woody debris were respectively 965 and $83 \mathrm{~g} \cdot \mathrm{m}^{-2} \cdot \mathrm{y}^{-1}$ in the GF and the HF (ANOVA, $p=$ 0.0014). The interannual mean flows of fwd in the GF and in HF were respectively $310 \mathrm{~g} \cdot \mathrm{m}^{-2} \cdot \mathrm{y}^{-1}$ and $51 \mathrm{~g} \cdot \mathrm{m}^{-2} \cdot \mathrm{y}^{-1}$. The flow of fwd in the GF is 8.5 times greater than that obtained in the HF.

\subsection{Classes of Decomposition of the CWD in Two Study Sites}

The results showed that in both forest types, the most important class of woody debris was class 3 with a rate of 44.18 percent in the GF and of 49.15\% in the HF. There are much more CWD of class 3 in the SF than CWD in GF. It also noted that woody debris of class 2 were most abundant in the HF (41.52\%) than in the GF (27.97\%). However, the rate of class 1 CWD was more important in the GF (27.86\%) than in the HF (9.33\%). In both forests no CWD class 4 not inventoried (Table 1 ).

\subsection{Mean Residence Time of Plant Woody Debris}

The mean residence time of CWD and FWD was calculated for both forests. The MRT refers to the time required for processing and the incorporation of organic matter into the soil compartment. For the CWD, the MRT in the GF was of 6.19 year against 25.99 year on the HF. For the fwd, the MRT was of 2.69 year and 1.99 year in the GF and $\mathrm{HF}$ respectively.

\subsection{Standing Woody Debris (Snag)}

The average stock in the two sites was very important. We obtained HF is obtained an average stock of $8805 \mathrm{~g} \cdot \mathrm{m}^{-2}$ and $5945 \mathrm{~g} \cdot \mathrm{m}^{-2}$ in HF and GF, respectively (ANOVA, $p=0.69$ ).

\subsection{Stock and Flow of Carbon Entering the Soil of Two Forest Ecosystems}

Considering that the rate of carbon into the dry matter is $0.5 \%$, the total stock of carboncontained in cwdwas 5496 GC in the FG and 7087 GC in HF. There are flowes of carbon of 888 and $272 \mathrm{gC} \cdot \mathrm{m}^{-2} \cdot \mathrm{y}^{-1}$ in the GF and the HF for the cwd respectively. For the fwd, we obtained a flow of carbon respective of 180 and $21 \mathrm{gC}^{-2} \mathrm{~m}^{-2} \cdot \mathrm{y}^{-1}(\mathrm{Table} 2)$.

The total stock of carbon (in cwd and fwd) in both forest types was of $5978 \mathrm{~g} \cdot \mathrm{m}^{-2}$ in the GF and $7128 \mathrm{gC} \cdot \mathrm{m}^{-2}$ in the HF. Total carbon floweswere $1068 \mathrm{gC} \cdot \mathrm{m}^{-2} \cdot \mathrm{y}^{-1}$ and $293 \mathrm{gC} \cdot \mathrm{m}^{-2} \cdot \mathrm{y}^{-1}$ (Table 3).

Table 1. Proportion of cwdin the GF and HF decay classes.

\begin{tabular}{lccc}
\hline & GF \% & SF \% \\
\hline Class 1 & 27.86 & 9.33 \\
Class 2 & 27.97 & 41.52 \\
Class 3 & 44.18 & 49.15 \\
Class 4 & 0 & 0 \\
\hline
\end{tabular}


Table 2. Stock and flow of carbon in the FG and the HF.

\begin{tabular}{ccccc}
\hline Type of forest & Stock $(\mathrm{pdl}) \mathrm{gC} \cdot \mathrm{m}^{-2}$ & Flow de pdl $\left(\mathrm{gC} \cdot \mathrm{m}^{-2} \cdot \mathrm{an}^{-1}\right)$ & Stock $(\mathrm{pdl})\left(\mathrm{gC} \cdot \mathrm{m}^{-2}\right)$ & Flow de $\mathrm{pdl}\left(\mathrm{gC} \cdot \mathrm{m}^{-2} \cdot \mathrm{y}^{-1}\right)$ \\
\hline FG & 5496 & 888 & 482 & 180 \\
FS & 7087 & 272 & 41 & 21 \\
\hline
\end{tabular}

Table 3. Total Carbon Stocks of cwd and fwd in the GF and the HF.

\begin{tabular}{ccc}
\hline Type of forest & Total stock $\mathrm{gC} \cdot \mathrm{m}^{-2}$ & Total flow $\left(\mathrm{g} \cdot \mathrm{m}^{-2} \cdot \mathrm{an}^{-1}\right)$ \\
\hline GF & 5978 & 1068 \\
HF & 7128 & 293 \\
\hline
\end{tabular}

\section{Discussion}

\subsection{Stock and Plant Woody Debris Flow}

Averages stock of coarse and fine woody debris obtained in our study are not closed to averages stocks of CWD obtained in others studies (Krauss et al., 2005; Wendy et al., 2006; Vogt, 1991; Wilcke et al., 2005; Jomura et al., 2007) but our results were closed to those obtained by others authors $\mathrm{f}$ in tropical's forests (Linder et al. 1997; Grove et al. 2001; Harmon et al., 1986) Table 4.

Several studies have shown that the amount of woody debris in an ecosystem is dependent on different factors: as age, structure and biomass of the forest on flor (Siipola et al., 1998). Other factors such as storms, hurricanes can also have an impact not only on the stocks but also the flow of on plant woody debris. Harmon et al. (1986) argue in fact that among the factors that contribute to the production plant woody debris and their accumulation on forest floor, there is the action of the winds. Inventory done in November 2007, a year after the first one made in 2006 inside the two sites has proved an important flow of coarse and fine woody debris plant.

For coarse woody debris were noted a difference of1895 $\mathrm{g} \cdot \mathrm{m}^{-2}$ compared to the volume measured the previous year. The HF noted an increase of $595 \mathrm{~g} \cdot \mathrm{m}^{-2}$ in comparison with the initial stock of CWD in this forest.

The action of strong winds in these two forests caused the fall of several trees and then of the plant woody debris also. Forest structures of the two forests associated with weather phenomena appear to our eyes as the first two explanatory factors of the unequal mean woody debris flow in both forest types. Interannual variability of the flow of FWD that we have registered gives an average flow of $203 \pm 182 \mathrm{~g} \cdot \mathrm{m}^{-2}$ in the GF against $57 \pm 82 \mathrm{~g} \cdot \mathrm{m}^{-2}$ on the HF.

Another factor that could explain the variability of stocks and flow of plant woody debris is the environment in which the forest grows. Indeed the GF forest settled along the Lesiolouna River. Water availability associated with better uptake of nutrients by the root system may indeed justify the coarse production of this forest in comparison with the hill-slope forest clump. The HF forest was developed on a slope of Hill. The water availability could also explain the low production of CWD than fwd in the HF compared to the GF.

Clark et al. (2002) in their studies on stocks and flow of coarse woody debris along a topographic gradient in relation to mineral availability not found the significant effect of these two factors on stocks and flow of the productions of woody debris. They affirmed also that they have not noted net effect due to the study area which was not enough large to test this effect.

\subsection{On the Method of Study}

Often criticism against the line transect method focuses on the total length of the transect during inventory in a forest ecosystem. In our study, the two diagonals by plot correspond to a total distance of $100 \mathrm{~m}$, and for the whole of the gallery forest or hill-slope forest clump is of 300 meters. Harmon \& Sexton (1996) advised for studies of dead wood stocks estimated a length that was not less than $100 \mathrm{~m}$, especially when the site had a high density in plant woody debris. In our case, if we have applied a single diagonal by plot the quantities of dead wood stocks should be reduced by approximately 45 percent where the importance of this parameter for representative averages. The experimental plots surface in our study is $40 \mathrm{~m} \times 40 \mathrm{~m}$ this surface is greater than that adopted by 
Table 4. Synthesis results of Necromass of stock and flow of coarse and fine woody debris.

\begin{tabular}{|c|c|c|c|c|c|c|c|}
\hline $\begin{array}{l}\text { Auteurs et } \\
\text { années }\end{array}$ & Type de forest & Flow & Turnover & Stock (Bibliography) & Stock $\left(\mathrm{Mg} \cdot \mathrm{ha}^{-1}\right)$ & Stock $\left(\mathrm{g} \cdot \mathrm{m}^{-2}\right)$ & $\begin{array}{c}\text { Flow } \\
\left(\mathrm{g} \cdot \mathrm{m}^{-2} \cdot \mathrm{y}^{-1}\right)\end{array}$ \\
\hline $\begin{array}{l}\text { Pedlar et al., } \\
2002\end{array}$ & $\begin{array}{l}\text { Coniferous } \\
\text { and deciduous }\end{array}$ & & & $160.80 \pm 15.43 \mathrm{~m}^{3} \cdot \mathrm{ha}^{-1}$ & $77.18 \pm 7.41$ & $77,180 \pm 7410$ & \\
\hline $\begin{array}{l}\text { Pedlar et al., } \\
2002\end{array}$ & Deciduous forest & & & $105.29 \pm 14.05 \mathrm{~m}^{3} \cdot \mathrm{ha}^{-1}$ & $50.54 \pm 6.74$ & $50,540 \pm 6740$ & \\
\hline $\begin{array}{l}\text { Pedlar et al., } \\
2002\end{array}$ & Coniferous forest & & & $17.81 \pm 4.64 \mathrm{~m}^{3} \cdot \mathrm{ha}^{-1}$ & $8.5488 \pm 2.222$ & $85,488 \pm 2222$ & \\
\hline $\begin{array}{l}\text { Krauss et al., } \\
2005\end{array}$ & Mangrove & & & $67 \mathrm{~m}^{3} \cdot \mathrm{ha}^{-1}$ & 32.16 & 3216 & \\
\hline $\begin{array}{l}\text { Wendy et al., } \\
2006\end{array}$ & Mean latitude forest & & & $0.61 \pm 0.29 \mathrm{Mg} \mathrm{C} \cdot \mathrm{ha}^{-1} \cdot \mathrm{an}^{-1}$ & $0.61 \pm 0.29$ & $610 \pm 290$ & \\
\hline $\begin{array}{l}\text { Grove et al., } \\
2001\end{array}$ & Rain tropical forest & & & $35.68 \mathrm{~m}^{3} \cdot \mathrm{ha}^{-1}$ & 17.13 & 17,130 & \\
\hline $\begin{array}{l}\text { Grove et al., } \\
2001\end{array}$ & Rain tropical forest & & & $20.16 \mathrm{~m}^{3} \cdot \mathrm{ha}^{-1}$ & 9.68 & 9680 & \\
\hline $\begin{array}{l}\text { Grove et al., } \\
2001\end{array}$ & Rain tropical forest & & & $\begin{array}{l}\mathrm{Vs}=27.00 \mathrm{~m}^{3} \cdot \mathrm{ha}^{-1} \\
-10.01 \mathrm{~m}^{3} \cdot \mathrm{ha}^{-1}\end{array}$ & $12.96 \pm 4.80$ & 12,960 & \\
\hline $\begin{array}{l}\text { Fraver et al., } \\
2002\end{array}$ & Central forest, USA & & & $\mathrm{V}=108.9 \mathrm{~m}^{3} \cdot \mathrm{ha}^{-1}$ & 23.22 & 23,220 & \\
\hline $\begin{array}{l}\text { Baker et al., } \\
2007\end{array}$ & $\begin{array}{c}\text { South } \\
\text { Amazonian forest }\end{array}$ & & & $\begin{array}{l}24.4 \pm 5.3 \mathrm{Mg} \cdot \mathrm{ha}^{-1} \\
\text { (transect) }\end{array}$ & $24.4 \pm 5.3$ & $24,400 \pm 5300$ & \\
\hline $\begin{array}{l}\text { Baker et al., } \\
2007\end{array}$ & Amazonian forest & & & $17.7 \pm 2.4 \mathrm{Mg} \cdot \mathrm{ha}^{-1}$ & $17.7 \pm 2.4$ & $17,700 \pm 2400$ & \\
\hline $\begin{array}{l}\text { Gough et al. } \\
\text { (2007) }\end{array}$ & Temperate forest & & & $2.2 \mathrm{Mg} \cdot \mathrm{C} \cdot \mathrm{ha}^{-1}$ & 2.2 & 22,000 & \\
\hline $\begin{array}{c}\text { Muller \& } \\
\text { Yan (1991) }\end{array}$ & $\begin{array}{l}\text { Deciduous } \\
\text { temperate forest }\end{array}$ & & & $22-49 \mathrm{Mg} \cdot \mathrm{ha}^{-1}$ & $22-49$ & $22,000 \pm 49,000$ & \\
\hline Vogt (1991) & Temperate forest & & & $2.2 \mathrm{Mg} \cdot \mathrm{C} \cdot \mathrm{ha}^{-1}$ & 2.2 & 2200 & \\
\hline $\begin{array}{l}\text { Baker et al., } \\
2007\end{array}$ & $\begin{array}{l}\text { Forest of south } \\
\text { Amazonian }\end{array}$ & $\begin{array}{c}3.8 \pm 0.2 \\
\mathrm{Mg} \cdot \mathrm{ha}^{-1} \cdot \mathrm{an}^{-1}\end{array}$ & & & & & $3800 \pm 200$ \\
\hline $\begin{array}{l}\text { Eaton } 2005 \\
\text { (Thèse) }\end{array}$ & $\begin{array}{c}\text { Forest of } \\
\text { south Mexico }\end{array}$ & & & 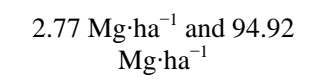 & 2.77; 94.92 & 2770 - 94,920 & \\
\hline $\begin{array}{l}\text { Eaton } 2005 \\
\text { (Thèse) }\end{array}$ & $\begin{array}{c}\text { Forest of } \\
\text { south Mexico. }\end{array}$ & & & $\begin{array}{c}\text { "2.66 Mg.ha- }{ }^{-1}(\mathrm{HF}) \text { and } \\
5.96 \mathrm{Mg} \cdot \mathrm{ha}^{-1}(\mathrm{FM})\end{array}$ & & & \\
\hline $\begin{array}{l}\text { Lee et al., } \\
1997\end{array}$ & Alberta & & & $101.4 \mathrm{~m}^{3} \cdot \mathrm{ha}^{-1}$ & 48.672 & 48,672 & \\
\hline $\begin{array}{l}\text { Clark et al. } \\
\text { (2002) }\end{array}$ & Costa Rica & $\begin{array}{c}4.9 \\
\mathrm{Mg} \cdot \mathrm{ha}^{-1} \cdot \mathrm{an}^{-1}\end{array}$ & & & & & 4900 \\
\hline $\begin{array}{l}\text { Chambers } \\
\text { et al. (2001) }\end{array}$ & Brasília & $3.6 \mathrm{ha}^{-1} \cdot \mathrm{an}^{-1}$ & & & & & \\
\hline $\begin{array}{l}\text { Harmon } \\
\text { et al., } 1986\end{array}$ & North America forest & & & $17.8 \mathrm{~m}^{3} \cdot \mathrm{ha}^{-1}$ & 8.544 & 8544 & \\
\hline $\begin{array}{l}\text { Siipola } \\
\text { et al., } 1998\end{array}$ & $\begin{array}{c}\text { Forêt de } \\
\text { Sapin, Finlande }\end{array}$ & & & $19.4 \mathrm{~m}^{3} \cdot \mathrm{ha}^{-1}$ & 9.31 & 9310 & \\
\hline $\begin{array}{l}\text { Rice et al. } \\
\text { (2004) }\end{array}$ & Brasilia & $\begin{array}{c}4.8 \\
\mathrm{Mg} \cdot \mathrm{ha}^{-1} \cdot \mathrm{an}^{-1}\end{array}$ & & & & & 4800 \\
\hline $\begin{array}{c}\text { Linder et al., } \\
1997\end{array}$ & $\begin{array}{l}\text { Boreal forest } \\
\text { (snag, Logs) }\end{array}$ & & & 27- $201 \mathrm{~m}^{3} \cdot \mathrm{ha}^{-1}$ & $12.96-96.48$ & $12,960-96,480$ & \\
\hline $\begin{array}{l}\text { Clark et al. } \\
\text { (2007) }\end{array}$ & $\begin{array}{l}\text { Tropical forest } \\
\text { of Costa Rica }\end{array}$ & $\begin{array}{l}\text { 4.9 Mg.hä }{ }^{-1}- \\
2.4 \mathrm{Mg} \cdot \mathrm{C} \cdot \mathrm{ha}^{-1}\end{array}$ & 9 years & 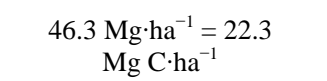 & & & 2400 \\
\hline $\begin{array}{l}\text { Baker et al., } \\
2004\end{array}$ & $\begin{array}{l}\text { Tropical forest } \\
\text { of Peru }\end{array}$ & $\begin{array}{l}3.8 \pm 0.2 \\
\mathrm{Mg}^{-1} \mathrm{ha}^{-1}\end{array}$ & $4.7 \pm 2.6$ years & $\begin{array}{l}24.4 \pm 5.3 \mathrm{Mg} \cdot \mathrm{ha}^{-1} \\
\text { (transect) }\end{array}$ & & & $3800 \pm 200$ \\
\hline $\begin{array}{l}\text { Baker et al., } \\
2004\end{array}$ & $\begin{array}{l}\text { Tropical forest } \\
\text { of Peru }\end{array}$ & & $4.7 \pm 2.6$ years & $17.7 \pm 2.4 \mathrm{Mg} \cdot \mathrm{ha}^{-1}$ & & & \\
\hline Gale (2000) & $\begin{array}{l}\text { Rainfall } \\
\text { tropical forest }\end{array}$ & & & $\begin{array}{l}\text { Logs = } 96 \text { à } 154 \mathrm{~m}^{3} \cdot \mathrm{ha}^{-1} ; \\
\text { Snag }=54 \mathrm{~m}^{3} \cdot \mathrm{ha}^{-1}\end{array}$ & $46.08-73.92$ & $46,080-73,920$ & \\
\hline $\begin{array}{l}\text { Rahman } \\
\text { et al. (2008) }\end{array}$ & Australia & & & $\begin{array}{c}\mathrm{V}=83.9 \mathrm{~m}^{3} \cdot \mathrm{ha}^{-1} \text { (Logs) } \\
23.4 \mathrm{~m}^{3} \cdot \mathrm{ha}^{-1} \text { (snags) }\end{array}$ & 40.27 & 40,270 & \\
\hline $\begin{array}{l}\text { Wilcle et al., } \\
2005\end{array}$ & Equator & & & $\begin{array}{l}9.1 \mathrm{t}^{-1} \mathrm{a}^{-1} \text { with } 40 \% \\
\text { snag and } 60 \% \text { logs }\end{array}$ & $5.46\left(\right.$ t.ha $\left.{ }^{-1}\right)$ & 546 & \\
\hline $\begin{array}{l}\text { Jomura et al., } \\
2007\end{array}$ & & & & $\begin{array}{l}9.30 \text { thha }^{-1} \text { with } \\
60 \% \text { snag. }\end{array}$ & 5.58 t.ha ${ }^{-1}$ & 558 & \\
\hline
\end{tabular}


McKenzie et al. (2000), because they use a surface of $25 \mathrm{~m} \times 25 \mathrm{~m}$ with a total length of $20 \mathrm{~m}$ only transect. We can conclude that the method used in addition to the inventory surface reassures us on the accuracy of the results obtained in our study of stocks and flows of plant woody debris.

We can conclude that the method used in addition to the sampling surface reassures us on the accuracy of the results obtained in our study of stocks and flow of plant woody debris.

\section{Acknowledgements}

The skilful technical assistance of Pierre Mbemba during data collection in the field is gratefully acknowledged. Our thanks are also due to the staff of gorilla sanctuary (John Espinall Foundation) for their support during field measurements and the Ministry of Sustainable Management forest for granting us permission to work in the gorilla sanctuary. S. Ifo was granted by the International Foundation for Science.

\section{References}

Baker, T. R., Coronado, E. N. H., Phillips, O. L., Martin, J., Van der Heijden, G. M. F., Garcia, M., \& Espejo, J. S. (2007). Low Stocks of Coarse Woody Debris in a Southwest Amazonian Forest. Oecologia, 152, 495-504. http://dx.doi.org/10.1007/s00442-007-0667-5

Baker, T. R., Phillips, O. L., Malhi, Y., Almeida, S., Arroyo, L., Di Fiore, A., Erwin, T., Killen, T. J., Laurance, S. G., Laurance, L. W., Lewis, S., Lloyd, J., Monteagudo, A., Neill, D. A., Patiño, S., Pitman, N. C. A., Silva, N. M., \& Vásquez, R. (2004a). Variation in Wood Density Determines Spatial Patterns in Amazonian Forest Biomass. Global Change Biology, 10, 545-562. http://dx.doi.org/10.1111/j.1365-2486.2004.00751.x

Beets, P. N., Hood, I. A., Kimberley, M. O., Olivier, G. R., Pearce, S. H., \& Garder, J. F. (2008). Coarse Woody Debris Decay Rates for Seven Indigenous Tree Species in the Central North Island of New Zealand. Forest Ecology and Management, 256, 548-557. http://dx.doi.org/10.1016/j.foreco.2008.05.036

Bernhard-Reversat, F. (1993). Dynamics of Litter and Organic Matter at the Soil Litter Interface in Fast-Growing Tree Plantations on Sandy Ferrallitic Soils (Congo). Acta Ecology, 14, 179-195.

Chambers, J. Q. (1998). The Role of Coarse Wood in the Carbon Cycle of Central Amazon Rain Forest. Ph.D. Dissertation, Santa Barbara: University of California.

Chambers, J., Schimel, J. P., \& Nobre, A. D. (2001). Respiration from Coarse Woody Litter in Central Amazon Forests. Biogeochemistry, 52, 115-131. http://dx.doi.org/10.1023/A:1006473530673

Chee, Y. E. (1999). A Comparison of Carbon Budgets for a Pinusradiata Plantation and a Native Eucalypt Forest in Bago State Forest, New South Wales (B.Sc. Honours Thesis). Canberra: Department of Geography, Australian National University.

Clark, D. B., Clarck, D. A., Brown, S., Oberbaver, S. F., \& Veldkamp, E. (2002). Stocks and Flowflow of Coarse Woody Debris across a Tropical Rain Forest Nutrient and Topography Gradient. Forest Ecology and Management, 164, $237-248$. http://dx.doi.org/10.1016/S0378-1127(01)00597-7

Clark, D. F., Kneeshaw, D. D., \& Antos, J. A. (1998). Coarse Woody Debris in Subboreal Spruce Forests of West-Central British Columbia. Canadian Journal of Forest Research, 28, 284-290. http://dx.doi.org/10.1139/x97-208

Delegue, M. A., Fuhr, M., Schwartz, D., Mariotti, A., \& Nasi, R. (2001). Recent Origin of a Large Part of the Forest Cover in the Gabon Coastal Area Based on Stable Carbon Isotope Data. Oecologia, 129, 106-113. http://dx.doi.org/10.1007/s004420100696

Eaton, J. M., \& Lawrence, D. (2006). Woody Debris Stocks and Flowes during Succession in a Dry Tropica Forest. Forest Ecology and Management, 232, 46-55. http://dx.doi.org/10.1016/j.foreco.2006.05.038

Eaton, M. J. (2005). Woody Debris and the Carbon Budget of Hill-Slope Forest Clump s in the Southern Yucatán Peninsular Region. Charlottesville: University of Virginia, 84 p.

Ekouloungou, R., Liu, X., Loumeto, J., Ifo, S., Bocko, Y., Koula, F., \& Niu, S. (2014). Tree Allometry in Tropical Forest of Congo for Carbon Stocks Estimation in Above-Ground Biomass. Open Journal of Forestry, 4, 481-491.

http://dx.doi.org/10.4236/ojf.2014.45052

Favier, C., Chave, J., Fabing, A., Schwartz, D., \& Dubois, M. A. (2004). Modelling Forest-Savanna Mosaic Dynamics in Man-Influenced Environments: Effects of Fire, Climate and Soil Heterogeneity. Ecological Modelling, 171, 85-102. http://dx.doi.org/10.1016/j.ecolmodel.2003.07.003

Fraver, S., Wagner, R. G., \& Day, M. (2002). Dynamics of Coarse Woody Debris Following Gap Harvesting in the Acadian Forest of Central Maine, USA. Canadian Journal of Forest Research, 32, 2094-2105. http://dx.doi.org/10.1139/x02-131 
Gale, N. (2000). The Aftermath of Tree Death: Coarse Woody Debris and the Topography in Four Tropical Rain Forests. Canadian Journal of Forest Research, 30, 1489-1493. http://dx.doi.org/10.1139/x00-071

Goma-Tchimbakala, J., \& Berhard-Reversat, F. (2006). Comparison of Litter Dynamics in Three Plantations of an Indigenous Timber Species (Terminalia superb) and a Natural Tropical Forest in Mayombe, Congo. Forest Ecology and Management, 229, 304-313. http://dx.doi.org/10.1016/j.foreco.2006.04.009

Gough, C. M., Vogel, C. S., Kazanski, C., Nagel, L. N., Flower, C. E, \& Curtis, P. S. (2007). Coarse Woody Debris and the Carbon Balance of a North Temperate Forest. Forest Ecology and Management, 244, 60-67. http://dx.doi.org/10.1016/j.foreco.2007.03.039

Gove, J. H., Ducey, M. J., \& Valentine, H. T. (2002). Multistage Point Relascope and Randomized Branch Sampling for Downed Coarse Woody Debris Estimation. Forest Ecology and Management, 155, 153-162. http://dx.doi.org/10.1016/S0378-1127(01)00555-2

Grove, S. J. (2001). Extent and Composition of Dead Wood in Australia Lowland Tropical Rainforest with Different Management History. Forest Ecology and Management, 154, 35-53. http://dx.doi.org/10.1016/S0378-1127(00)00618-6

Harmon, M. E., \& Sexton, J. (1996). Guidelines for Measurements of Woody Detritus in Forest Ecosystems. US LTER Publication No. 20, Seattle, WA: University of Washington, 73 p.

Harmon, M. E., Franklin, J. F., Swanson, F. J., Sollins, P., Gregory, S. V., Lattin, J. D., Anderson, N. H., Cline, P., Aumen, N. G., Sedell, J. R., Lienkaemper, G. W., Cromack Jr., K., \& Cummins, K. W. (1986). Ecology of Coarse Woody Debris in Temperate Ecosystems. Advances in Ecological Research, 15, 133-302. http://dx.doi.org/10.1016/S0065-2504(08)60121-X

Jessen, R. J. (1955). Determining the Fruit Count on a Tree by Randomized Branch Sampling. Biometrics, 11, 99-109. http://dx.doi.org/10.2307/3001484

Jiménez, E. M., Moreno, F. H., Lloyd, J., Penuela, M. C., \& Patino, S. (2009). Fine Root Dynamics for Forests on Contrasting Soils in the Colombian Amazon. Biogeosciences Discussions, 6, 3415-3453. http://dx.doi.org/10.5194/bgd-6-3415-2009

Jomura, M., Kominami, Y., Tamai, K., Miyama, T., Goto, Y., Dannoura, M., \& Kanazawa, Y. (2007). The Carbon Budget of Coarse Woody Debris in a Temperate Broad-Leaved Secondary Forest in Japan. Tellus B, 59, 211-222. http://dx.doi.org/10.1111/j.1600-0889.2006.00234.x

Jourdan, C., Silva, E. V., Goncalves, J. L. M., Ranger, J., Moreira, R. M., \& Laclau, J. P. (2008). Fine Root Production and Turnover in Brazilian Eucalyptus Plantations under Contrasting Nitrogen Fertilization Regimes. Forest Ecology and Management, 256, 396-404. http://dx.doi.org/10.1016/j.foreco.2008.04.034

Karjalainen, L., \& Kuuluvainen, T. (2002). Amount and Diversity of Coarse Woody Debris within a Boreal Forest Landscape Dominated by Pinussylvestris in Vienansalo Wilderness, Eastern Fennoscandia. Silva Fennica, 36, 147-167.

Kraigher, H., Jurc, D., Kalan, P., Kunar, L., Levanic, T., Rupel, M., \& Smolej, I. (2002). Beech Coarse Woody Debris Characteristics in Two Virgin Forest Reserves in Southern Slovenia. Zbomikgozdarstva in Lesarstva, 69, 91-134.

Krauss, K. W., Doyle, T. W., Twilley, R. R., Smith, J. T., Whelan, K. R. T., \& Sullivan, J. (2005). Woody Debris in the Mangrove Forests of South Florida. Biotropica, 37, 9-15. http://dx.doi.org/10.1111/j.1744-7429.2005.03058.x

Lambert, R. L., Lang, G. E., \& Reiners, W. A. (1980). Loss of Mass and Chemical Change in Decaying Boles of a Subalpine Balsam Fir Forest. Ecology, 61, 1460-1473. http://dx.doi.org/10.2307/1939054

Linder, P., Elfving, B., \& Zackrisson, O. (1997). Stand Structure and Successional Trends in Virgin Boreal Forest Reserves in Sweden. Forest Ecology and Management, 98, 17-33. http://dx.doi.org/10.1016/S0378-1127(97)00076-5

Loumeto, J. J. (2002). Les systèmes litières des forêts à peuplement d’Okoumé. (Aucoumea Klaineana): Exemple de 2 sites congolais, La forêt du Chaillu et la forêt du littoral. Thèse, Paris: Université Paris VI, 159 p.

Maser, C., Trappe, J. M., Cline, S. P. et al., Technical Editors (1984). The Seen and Unseen World of the Fallen Tree. Gen. Tech. Rep. PNW-GTR-164, Portland, OR: US Department of Agriculture, Forest Service, Pacific Northwest Research Station, $56 \mathrm{p}$.

McKenzie, N., Ryan, P., Fogarty, P., \& Wood, J. (2000). Sampling, Measurement and Analytical Protocols for Carbon Estimation in Soil, Litter and Coarse Woody Debris. National Carbon Accounting System Technical Report No. 14, Canberra: Australian Greenhouse Office.

Mitchard, E. T. A., Saatchi, S. S., Gerard, F. F., Lewis, S. L., \& Meir, P. (2009). Measuring Woody Encroachment along a Forest-Savanna Boundary in Central Africa. Earth Interact, 13, 1-29. http://dx.doi.org/10.1175/2009EI278.1

Muller, R. N., \& Yan, L. (1991). Coarse Woody Debris in an Old-Growth Deciduous Forest on the Cumberland Plateau, Southeastern Kentucky. Canadian Journal of Forest Research, 21, 1567-1572.

Nganga, D. (2011). Litterfall, Accumulation and Decomposition in the Forest Groves Established on Savannah in the Plateau Teke, Central Africa. Journal of Environmental Science and Technology, 4, 601-610. 
Pandey, R. R., Sharma, G., Tripathi, S. K., \& Singh, A. K. (2007). Litterfall, Litter Decomposition and Nutrient Dynamics in a Subtropical Natural Oak Forest and Managed Plantation in Northeastern India. Forest Ecology and Management, 240, 96-104. http://dx.doi.org/10.1016/j.foreco.2006.12.013

Pedlar, J. H., Pearce, J. L., Venier, L. A., \& McKenney, D. W. (2002). Coarse Woody Debris in Relation to Disturbance and Forest Type in Boreal Canada. Forest Ecology and Management, 158, 189-194. http://dx.doi.org/10.1016/S0378-1127(00)00711-8

Pesonen, A., Leino, O., Maltamo, M., \& Kangas, A. (2009). Comparison of Field Sampling Methods for Assessing Coarse Woody Debris and Use of Airborne Laser Scanning as Auxiliary Information. Forest Ecology and Management, 257, 1532-1541. http://dx.doi.org/10.1016/j.foreco.2009.01.009

Pittman, R. J. (2005). Coarse Woody Debris in Industrially Managed Pinustaeda Plantation of Southeastern United States. Master's Thesis, Blacksburg, VA: Virginia Polytechnics Institute and State University, 113 p.

Rahman, M. M., Franck, G., Ruprecht, H., \& Vacik, H. (2008). Structure of Coarse Woody Debris in Lange-Leitn Natural Forest Reserve, Austria. Journal of Forest Science, 54, 161-169.

Rice, A. H., Hammond-Pyle, E., Saleska, S. R., Hutyra, L., Palace, M., Keller, M., de Camargo, P. B., Portilho, K., Marques, D. F., \& Wofsy, S. C. (2004). Carbon Balance and Vegetation Dynamics in an Old-Growth Amazonian Forest. Ecological Applications, 114, 55-71. http://dx.doi.org/10.1890/02-6006

Samuelsson, J., Gustafsson, L., \& Ingelög, T. (1994). Dying and Dead Trees-A Review of Their Importance for Biodiversity. Uppsala: Swedish Threatened Species Unit.

Schartz, D., Elenga, H., Vincens, A., Bertaux, J., Mariotti, A., Achoundong, G., Alexandre, A., Belingard, C., Girardin, C., Guillet, B., Maley, J., De Namur, C., Reynaud-Farrera, I., \& Youta Happi, J. (1996). Dans: M. Servant-Vildary (dir. Publ.). Dynamique à Long Terme des Ecosystèmes Forestiers Intertropicaux, 38, 325-338.

Schwartz, D., \& Namri, M. (2002). Mapping the Total Organic Carbon in the Soils of the Congo. Global Planetary Change, 33, 77-93. http://dx.doi.org/10.1016/S0921-8181(02)00063-2

Siipola, A. L., Siitonen, J., \& Kallio, R. (1998). Amount and Quality of Coarse Woody Debris in Natural and Managed Coniferous Forest near the Timberline in Finnish Lapland. Scandinavian Journal of Forest Research, 13, 204-214. http://dx.doi.org/10.1080/02827589809382978

Turner, D. P., Koerper, G. J., Harmon, M. E., \& Lee, J. J. (1995). A Carbon Budget for Forests of the Conterminous United States. Ecological Applications, 5, 421-436. http://dx.doi.org/10.2307/1942033

Vincens, A., Schwartz, D., Elenga, H., Reynaud-Farrera, I., Alexandre, A. et al. (1999). Forest Response to Climate Changes in Atlantic Equatorial Africa during the Last 4000 Years BP and Inheritance on the Modern Landscapes. Journal of Biogeography, 26, 879-885. http://dx.doi.org/10.1046/j.1365-2699.1999.00333.x

Vogt, K. A. (1991). Carbon Budgets of Temperate Forest Ecosystems. Tree Physiology, 9, 69-86. http://dx.doi.org/10.1093/treephys/9.1-2.69

Waren, W. G., \& Olsen, P. F. (1964). A Line Intersect Technique for Assessing Logging Waste. Forest Science, 10, 267276.

Wendy, H. L., David, M. B., Lucy, R. H., Scott, R. S., Elizabeth, H. P., Daniel, C., \& Steven, C. W. (2006). Woody Debris Contribution to the Carbon Budget of Electively Logged and Maturing Mid-Latitude Forests. Oecologia, 148, 108-117. http://dx.doi.org/10.1007/s00442-006-0356-9

Wilcke, W., Hess, T., Bengel, C., Homeier, J., Valarezo, C., \& Zech, W. (2005). Coarse Woody Debris in a Montane Forest in Ecuador: Mass, C and Nutrient Stock, and Turnover. Forest Ecology and Management, 205, 139-147. http://dx.doi.org/10.1016/j.foreco.2004.10.044

Woldendorp, G., Keenan, R. J., \& Ryan, M. F. (2002). An Analysis of Sampling Methods for Coarse Woody Debris in Australian Forest Ecosystems: A Report for the National Greenhouse Strategy, Module 6.6 (Criteria and Indicators of Sustainable Forest Management). Canberra: Bureau of Rural Sciences, 94 p.

Woodall, C. W., \& Liknes, G. C. (2008). Relationships between Forest Fine and Coarse Woody Debris Carbon Stocks across Latitudinal Gradients in the United States as an Indicator of Climate Change Effects. Ecological Indicators, 8, 686-690. http://dx.doi.org/10.1016/j.ecolind.2007.11.002 
Scientific Research Publishing (SCIRP) is one of the largest Open Access journal publishers. It is currently publishing more than 200 open access, online, peer-reviewed journals covering a wide range of academic disciplines. SCIRP serves the worldwide academic communities and contributes to the progress and application of science with its publication.

Other selected journals from SCIRP are listed as below. Submit your manuscript to us via either submit@scirp.org or Online Submission Portal.
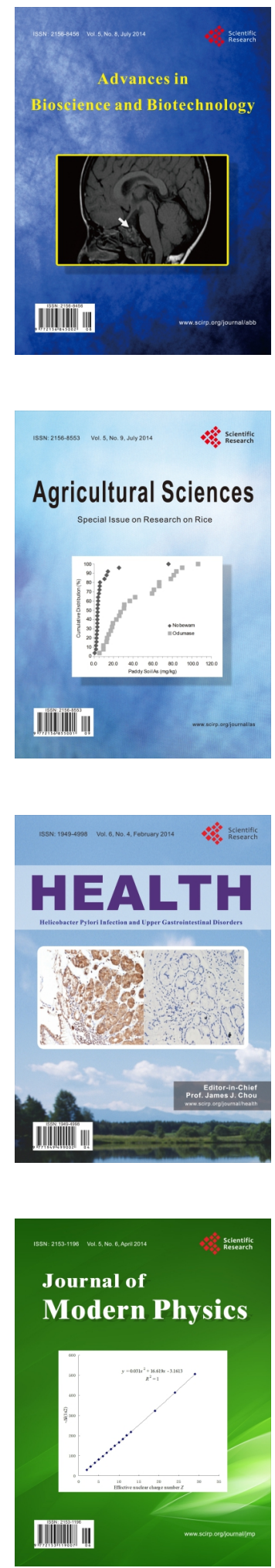
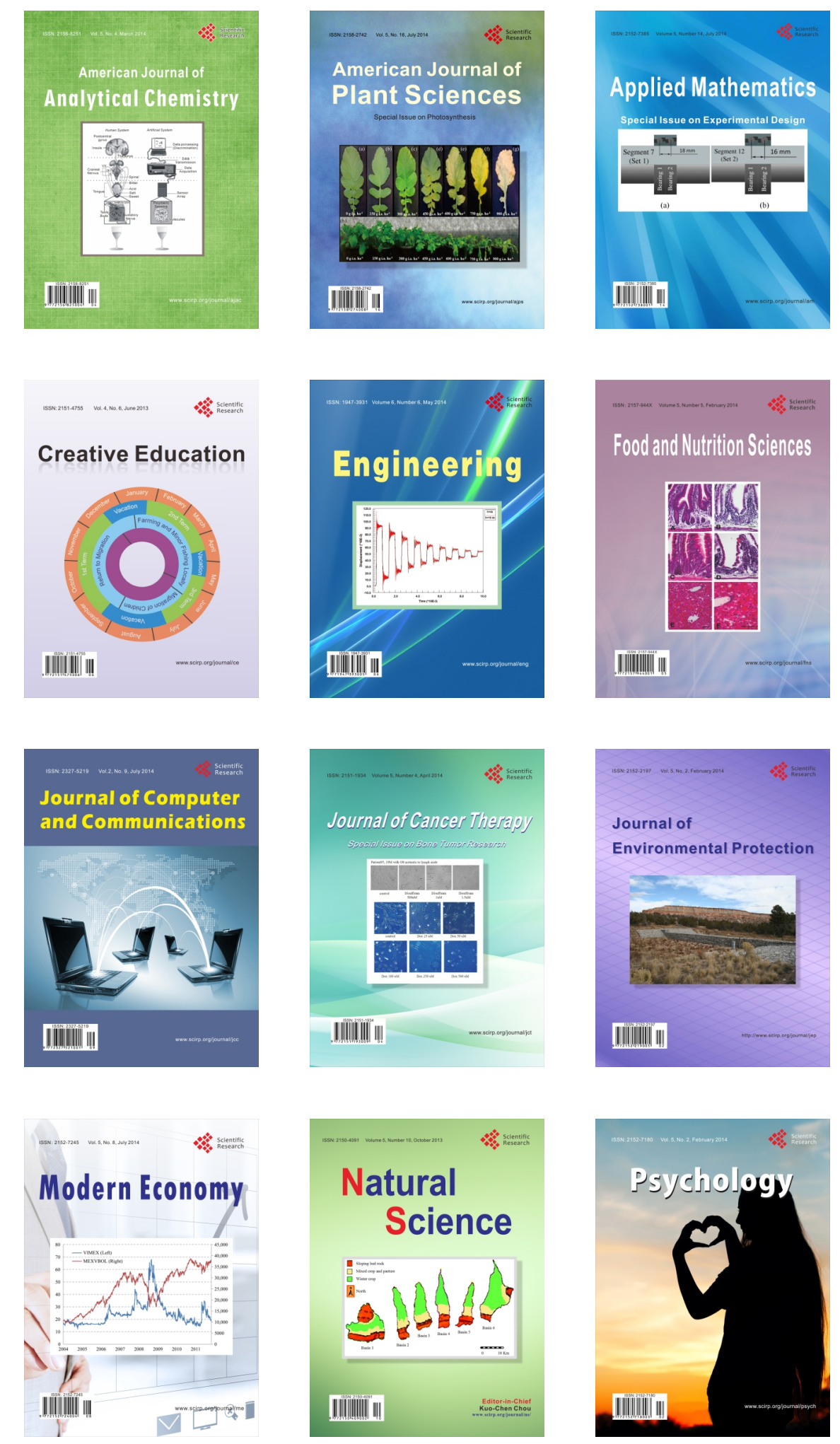